\title{
Profiles of energy metabolites and haptoglobin in dairy cows under organic management in Alberta farms
}

\author{
John F. Odhiambo ${ }^{1,2}$, Umar Farooq ${ }^{1}$, Suzanna M. Dunn ${ }^{1}$, Burim N. Ametaj $^{{ }^{*}}$ \\ ${ }^{1}$ Department of Agricultural, Food and Nutritional Science, University of Alberta, Edmonton, Canada; \\ *Corresponding Author: burim.ametaj@ualberta.ca \\ ${ }^{2}$ Department of Animal Science, University of Wyoming, Laramie, USA
}

Received 11 January 2013; revised 21 February 2013; accepted 29 March 2013

Copyright (C) 2013 John F. Odhiambo et al. This is an open access article distributed under the Creative Commons Attribution License, which permits unrestricted use, distribution, and reproduction in any medium, provided the original work is properly cited.

\section{ABSTRACT}

Profiles of energy metabolites and haptoglobin $(\mathrm{Hp})$ in dairy cows that are transitioned from conventional to organic management in various Alberta farms were compared with those of dairy cows managed conventionally at the University of Alberta dairy farm. Blood samples were collected during the following periods: Dry, 0 - 30, 30 - 60, and 60 - 90 days in milk (DIM, $n=7$ cows). Concentrations of metabolites were evaluated by enzymatic colorimetric methods. Concentrations of $\mathrm{Hp}$ were determined by bovine ELISA kits. Data were analyzed by the mixed procedures of SAS. Concentrations of NEFA and BHBA in blood were elevated $(P<0.001) 0$ to 30 $\mathrm{d}$, intermediate 30 to 60 , and 60 to $90 \mathrm{~d}$, and lower in the dry period. In addition, BHBA was higher $(P<0.0001)$ at all stages of lactation in conventional than organic cows (e.g. $1289.4 \pm$ 88.6 vs. $883.6 \pm 47.5 \mu \mathrm{mol} / \mathrm{L}$ in conventional and organic cows at 0 - $30 \mathrm{~d}$, respectively). Serum concentrations of cholesterol increased with increasing DIM and returned to nadir levels during dry period and was higher $(P<0.0001)$ in conventional than organic cows. Low glucose concentrations were observed 0 to $30 \mathrm{~d}$, levels were intermediate 30 to 60 and 60 to $90 \mathrm{~d}$, and peaked during the dry period $(P<0.0001)$. However, glucose concentrations did not differ $(P<$ $0.54)$ between conventional and organic cows. Lactate did not $(P<0.24)$ vary with DIM or day $x$ farm type but was higher $(P<0.0001)$ in organic cows than in conventional cows. Serum concentrations of $\mathrm{Hp}$ were elevated during dry period; reached peak levels 0 to $30 \mathrm{~d}$ and decrea- sed gradually with increasing days postpartum and were much higher at all periods in conventional than organic cows. Overall, concentrations of $\mathrm{Hp}$ were $528.1 \pm \mathbf{4 5 . 2} \mu \mathrm{g} / \mathrm{mL}$ in conventional cows vs. $261.1 \pm 16.9 \mu \mathrm{g} / \mathrm{mL}$ in organic cows $(P<0.0001)$. Taken together, these data indicate that metabolic changes associated with initiation of lactation are preceded by an acute phase response in dairy cows, and that cows in organic systems seem to be healthier than cows under conventional systems. These differences might be due to differences in nutritional management in the two systems.

Keywords: Organic Cows; BHBA; NEFA; Haptoglobin

\section{INTRODUCTION}

Increasing consumer awareness about the environment and their desire to consume healthy products, produced without utilization of pesticides, antibiotics, or other chemicals are the essential reasons behind increasing demand for organic dairy products. As such, organic dairy industry has been growing rapidly in Canada and beyond. Although there is a great interest to be involved in transitioning from conventional to organic dairying, there is also uncertainty whether this change will affect the productivity and health of dairy cows and in the end the profitability of the new establishment.

In areas where cows are housed during a significant part of the year because of adverse weather conditions, composition of feed becomes the major difference between organic and conventional dairy farming. Nevertheless, organically managed dairy cows must be fed at least $95 \%$ organically produced feed, no genetically mo- 
dified products, and the total daily dry matter (DM) proportion of concentrate should not exceed $50 \%$ during the first 3 months of lactation and thereafter, not more than 40\% (Council of the European Communities, 1991). However, there are major differences between organic and conventional managements regarding the use of antibiotic and chemotherapeutic treatments and in handling of the animals. These include, doubled withdrawal period for delivery of milk after treatment with registered pharmaceuticals, anti-parasite strategy without drugs, fresh milk for raising calves, access to regular exercise, and a prolonged grazing season.

Negative energy balance (NEB) during early lactation is a major concern in organic dairy herds due to restrained use of concentrates [1]. As a consequence, body energy reserves primarily body fat is mobilized leading to increased concentrations of NEFA and BHBA in plasma [2-4]. Epidemiological studies on differences in energy metabolism between organic and conventional dairy cows are scarce. However, in a study by Roesch et al. [5], no differences in the blood metabolites NEFA, BHBA, or glucose were found around $30 \mathrm{~d}$ postpartum, nor were any differences found in BCS before or after calving, making the authors suggest that energy intake was not abnormal in any of the groups. A clinical manifestation of NEB is ketosis, and it has previously been studied in organic dairy cows. Hamilton et al. [6] found no signs of wide spread clinical or subclinical ketosis, whereas Hardeng and Edge [1] found markedly lower incidence of clinical ketosis in organic versus conventional cows. Fall et al. [7], reported no long-term differences in mobilization of energy from body tissue between organic and conventional dairy cows and concluded that organic dairy cows adjust their milk production to feed intake.

In this study, metabolite profiles of dairy cows that are transitioned from conventional to organic management have been evaluated. The objective of the study was to compare changes in metabolites in blood of dairy cows that are transited from conventional to organic management in various Alberta farms with those of dairy cows managed conventionally at the University of Alberta dairy farm.

\section{MATERIALS AND METHODS}

\subsection{Study Design and Selection of Farms and Cows}

All farms in the study were located in Alberta, Canada. To be included in this study, the dairy farms must have been producing milk under Canadian regulations of the organic dairy farms and utilize total mixed ration (TMR) in feeding regimen. In addition, the farms were required to have more than 100 dairy cows, and at least 7 or more cows available for each sampling group, i.e., dry period, fresh period $(0-30 \mathrm{~d}$ postpartum), early lactation (30 $60 \mathrm{~d}$ postpartum), and mid-lactation (60 - $90 \mathrm{~d}$ postpartum). Three organic farms (ORG) fulfilled these conditions and were recruited in the study. In addition, the university farm in Edmonton, Alberta was included as a conventional farm (CON) for comparative purpose. Breed composition in organic farms were $1 / 3$ Jersey cows and $2 / 3$ Holstein cows. However, in the conventional farm, all cows were of Holstein origin.

Based on the time relative to parturition, clinically healthy cows were allocated to one of the 4 groups in this study (i.e., dry period, $0-30 \mathrm{~d}, 30-60 \mathrm{~d}$, and $60-90 \mathrm{~d}$ postpartum). Each group contained 7 cows and, when possible, attention was paid that cows within a group have similar conditions such as lactation day, milk production, body weight. All ORG had free-stall barns, whereas the cows of CON were in tied-stalls. In all the farms, cows were fed a total mixed ration (TMR) once daily early in the morning ( 0700 to $0800 \mathrm{~h}$ ). A summary of rations utilized by the farms included in this study is given in Table 1. During samplings, the cows of the ORG were restrained at the milking parlors, whereas cows of the CON were restrained in their stalls.

\subsection{Sample Collection}

Blood samples were obtained by tail veinupuncture in $10 \mathrm{~mL}$ vacutainer tubes without anticoagulant (Becton Dickinson, Franklin Lake, NJ) and allowed to coagulate at room temperature. Serum was obtained following centrifuging at $3000 \times \mathrm{g}$ at $4^{\circ} \mathrm{C}$ for $20 \mathrm{~min}$ (Rotanta $460 \mathrm{R}$, Hettich Zentrifugan, Tuttlingen, Germany). Serum samples were stored at $-20^{\circ} \mathrm{C}$ until analysis.

\subsection{Blood Metabolites}

Blood metabolites analyzed included circulating glucose, non-esterified fatty acids (NEFA), $\beta$-hydroxy-butyrate (BHBA) cholesterol, and lactate.

The concentration of glucose in the serum was quantified by an enzymatic method by commercially available kits (Diagnostic Chemicals Ltd., Charlottetown, PA). Briefly, the procedure involves phosphorylation and oxidization of glucose in samples resulting in the production of NADH which produces a color proportional to the glucose concentration in the sample. All samples were tested in duplicates and the serum glucose was then determined by reading on a microplate spectrophotometer (Spectramax 190, Molecular Devices Corporation, CA) at an optical density of $340 \mathrm{~nm}$. According to the manufacture's instructions the lower detection limit of the testwas $0.06 \mathrm{mg} / \mathrm{dL}$.

Quantitative determination of serum NEFA was done by an enzymatic colorimetric method using commer 
Table 1. Composition of milking cow rations utilized by the farms during winter and summer periods ${ }^{1}$.

\begin{tabular}{|c|c|c|c|c|c|}
\hline & & \multicolumn{2}{|c|}{ Organic Farm } & \multicolumn{2}{|c|}{ Conventional Farm } \\
\hline & & Winter & Summer & Winter & Summer \\
\hline Ingredient & Unit of DM & Amount & Amount & Amount & Amount \\
\hline Crude Protein & $\%$ & 16.79 & 16.02 & 17.88 & 17.78 \\
\hline RUP & $\%$ of $\mathrm{CP}$ & 29.32 & 36.08 & 34.26 & 34.49 \\
\hline $\mathrm{ADF}$ & $\%$ & 19.97 & 20.15 & 20.83 & 21.38 \\
\hline NDF & $\%$ & 31.2 & 31.25 & 31.67 & 32.43 \\
\hline NELact. & $\mathrm{MCal} / \mathrm{Kg}$ & 1.71 & 1.68 & 1.84 & 1.81 \\
\hline Calcium & $\%$ & 0.9 & 1.04 & 1.00 & 1.03 \\
\hline Phosphorous & $\%$ & 0.38 & 0.34 & 0.46 & 0.45 \\
\hline Magnesium & $\%$ & 0.3 & 0.32 & 0.35 & 0.36 \\
\hline Sodium & $\%$ & 0.13 & 0.43 & 0.30 & 0.31 \\
\hline Potassium & $\%$ & 1.64 & 1.53 & 1.44 & 1.4 \\
\hline Copper & ppm & 25.91 & 26.27 & 43.63 & 42.19 \\
\hline Manganese & ppm & 111.7 & 119.92 & 81.81 & 79.11 \\
\hline Zinc & ppm & 137.45 & 126.04 & 125.44 & 121.31 \\
\hline Vitamin A & $\mathrm{KIU} / \mathrm{Kg}$ & 7.3 & 7.08 & 8.73 & 8.44 \\
\hline Vitamin D & $\mathrm{KIU} / \mathrm{Kg}$ & 1.37 & 1.37 & 1.53 & 1.48 \\
\hline Vitamin E & $\mathrm{IU} / \mathrm{Kg}$ & 47.08 & 45.71 & 59.99 & 58.02 \\
\hline
\end{tabular}

${ }^{1}$ Diets were fed as TMR once daily early in the morning from 0700 to $0800 \mathrm{~h}$.

cially available kits (Wako Chemicals, Richmond, VA). The principle of the test involves acylation of coenzyme A by fatty acids in the sample in presence of acyl-CoA synthetase and production of hydrogen peroxide in presence of acyl-CoA oxidase. Hydrogen peroxide, in presence of peroxidase, permits the oxidative condensation of 3 -methyl-N-ethyl-N- $\beta$-hydroxyethyl-O-aniline (MEHA) with 4-aminoantipyrine to form a purple colored adduct which is proportional to the NEFA in the sample. Samples were tested in duplicates and the optical density was measured at $550 \mathrm{~nm}$ on a microplate spectrophotometer (Spectramax 190, Molecular Devices Corporation, CA). The lower detection limit of the assay was $0.50 \mathrm{mEq} / \mathrm{L}$.

Enzymatic quantitation of BHBA by $\beta$-hydroxy butyrate dehydrogenase was used for quantifying serum concentration of BHBA using a commercially available kit (Stanbio Laboratory, Boerne, TX). The principle of the test involves conversion of BHBA in the samples to acetoacetate and NADH at $\mathrm{pH} 8.5$ by $\beta$-hydroxybutyrate dehydrogenase in the presence of NADH. The NADH produced reacts with INT in the presence of diaphorase to produce a color proportional to the concentration of BHBA in the sample. Serum BHBA was measured in duplicates by reading on a microplate spectrophotometer (Spectramax 190, Molecular Devices Corporation, CA) at an optical density of $505 \mathrm{~nm}$. The lower detection limit of the assay was $125 \mathrm{mmol} / \mathrm{mL}$.

Serum cholesterol was measured using commercially available kits (Diagnostic Chemicals Ltd., Charlottetown, PA). The colorimetric method is based on the principle of hydrolyzing the cholesterol esters to free cholesterol and oxidation of free cholesterol to cholest-4ene-3-one with simultaneous production of hydrogen peroxide. The hydrogen peroxide couples with 4-aminoantyrine and p-hydroxybenzoate, in the presence of peroxidase to yield a chromogen whose intensity is proportional to concentration of cholesterol in the sample. All samples were tested in duplicates and serum cholesterol was determined by reading the optical density values on a microplate spectrophotometer (Spectramax 190, Molecular Devices Corporation, CA) at $505 \mathrm{~nm}$.

Serum concentration of lactate was determined using commercially available lactate assay kits (Biomedical Research Service Center, Buffalo, NY). The principle of the test involves reduction of tetrazolium salt INT in a $\mathrm{NADH}$-coupled enzymatic reaction to formazan which 
exhibits a red color whose intensity is proportional to concentration of lactate. The lactate standard provided in the kit was diluted to set a detection range of 125 to 1000 $\mu \mathrm{M}$. All samples were tested in duplicates and the lactate concentration was determined by reading the optical density values on a microplate spectrophotometer (Spectramax 190, Molecular devices Corporation, CA) at 492 nm.

\subsection{Haptoglobin}

Concentrations of haptoglobin (Hp) in the samples were determined by using commercially available bovine ELISA kits Catalog number TP801 (Tridelta Development Ltd., Greystones, Co. Wicklow, Ireland). According to the manufacturer, the minimum detection limit of the assay was $2.5 \mathrm{mg} / \mathrm{mL}$ as defined by the linear range of standard curves. All samples were tested in duplicate, and the optical density at $630 \mathrm{~nm}$ was measured on a microplate spectrophotometer (Spectramax 190, Molecular Devices Corporation).

\section{STATISTICAL ANALYSES}

All data were analyzed using the mixed procedures of SAS (SAS Institute Inc., Cary, NC) according to the model shown below:

$$
\begin{aligned}
Y_{i j k m n}= & \mu+\alpha_{i}+\beta_{j}+(\alpha \beta)_{i j}+\chi_{k}+(\chi \beta)_{k j} \\
& +\delta(O)_{m}+\left(\delta_{(O)} \beta\right)_{m j}+e_{i j k m n}
\end{aligned}
$$

where $Y_{i j k m n}$ is the observations for dependent variables, $\mu$ is the overall population mean, $\alpha_{i}$ is a population parameter corresponding to the type of farm (CON. vs. ORG), $\beta_{j}$ is the fixed effect of stage of lactation $j, \chi_{k}$ is the fixed effect of season $k, \delta(O)_{m}$ is the fixed effect of breed $m$ within organic farms $O,(\alpha \beta)_{i j},(\chi \beta)_{k j}$ $\left(\delta_{(O)} \beta\right)_{m j}$ are the effects of a two-way interaction between stage of lactation and farm type, season, and breed, respectively, and $e_{i j k m n}$ is the residual error. The model was reduced when interactions involving breed were not observed. Significance was declared at $\mathrm{P} \leq 0.05$.

\section{RESULTS}

\subsection{Non-Esterified Fatty Acids (NEFA)}

Serum concentrations of NEFA were affected by breed $(\mathrm{P}<0.05)$, and the interaction of season by stage of lactation $(\mathrm{P}<0.002)$. In addition, concentrations of NEFA tended $(\mathrm{P}=0.06)$ to be affected by season but not by farm type, stage of lactation or their two way interactions $(\mathrm{P}<0.36)$.

Jersey cows had lower whereas Holstein cows had higher $(\mathrm{P}<0.05)$ serum concentrations of NEFA (198.2 \pm 22.2 vs. $240.3 \pm 13.9 \mathrm{mEq} / \mathrm{L}$, respectively). In addition, concentrations of NEFA were numerically higher $(\mathrm{P}<$ $0.06)$ in cows during winter than in the summer season $(236.4 \pm 16.5$ vs. $202.1 \pm 18.7 \mathrm{mEq} / \mathrm{L}$, respectively). During, the summer months, concentrations of NEFA were higher between 0 to $30 \mathrm{~d}$ postpartum, intermediate between 30 to $60 \mathrm{~d}$ and dry period, but lower between 60 to $90 \mathrm{~d}$ postpartum. However, for winter season, concentrations of NEFA were higher between 60 to $90 \mathrm{~d}$ postpartum but remained fairly constant during the other periods of study (Figure 1).

\section{2. $\beta$-Hydroxy-Butyrate (BHBA)}

Farm type $(\mathrm{P}<0.01)$, stage of lactation $(\mathrm{P}<0.0001)$ and farm type by stage of lactation $(\mathrm{P}<0.0001)$ affected serum concentrations of BHBA of the cows. In addition, season also tended $(\mathrm{P}=0.06)$ to affect serum concentrations of BHBA of the cows.

Serum concentrations of BHBA of cows under conventional management were higher $(\mathrm{P}<0.01)$ than those of cows under organic systems $(989.5 \pm 61.7 \mathrm{vs}$. $813.8 \pm$ $24.6 \mu \mathrm{mol} / \mathrm{L}$, respectively). Concentrations of BHBA were greater $(\mathrm{P}<0.0001)$ in the conventional than organic cows at 0 to 30 and 60 to $90 \mathrm{~d}$ postpartum, but remained lower during the dry period (Figure 2). No differences $(\mathrm{P}<0.3)$ were observed between the groups at 30 to $60 \mathrm{~d}$. During summer season, serum concentrations of BHBA in cows tended $(\mathrm{P}=0.06)$ to be lower than those observed during winter $(863.1 \pm 43.2$ vs. $940.3 \pm$ $37.6 \mu \mathrm{mol} / \mathrm{L}$, respectively).

\subsection{Cholesterol}

Serum concentrations of cholesterol of the cows were

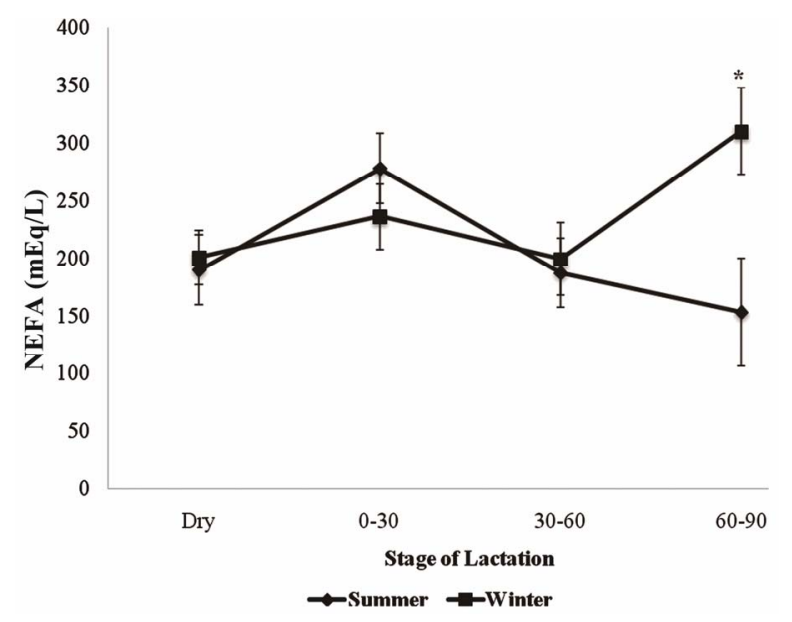

Figure 1. Least square means $\pm \mathrm{SE}$ serum concentrations of NEFA $(\mathrm{mEq} / \mathrm{L})$ in transition dairy cows. Blood samples were obtained from cows $(n=7)$ during the transition period and analyzed for metabolite content by ELISA. "LS means for season $\times$ stage of lactation differed $(\mathrm{P}<0.002)$. 


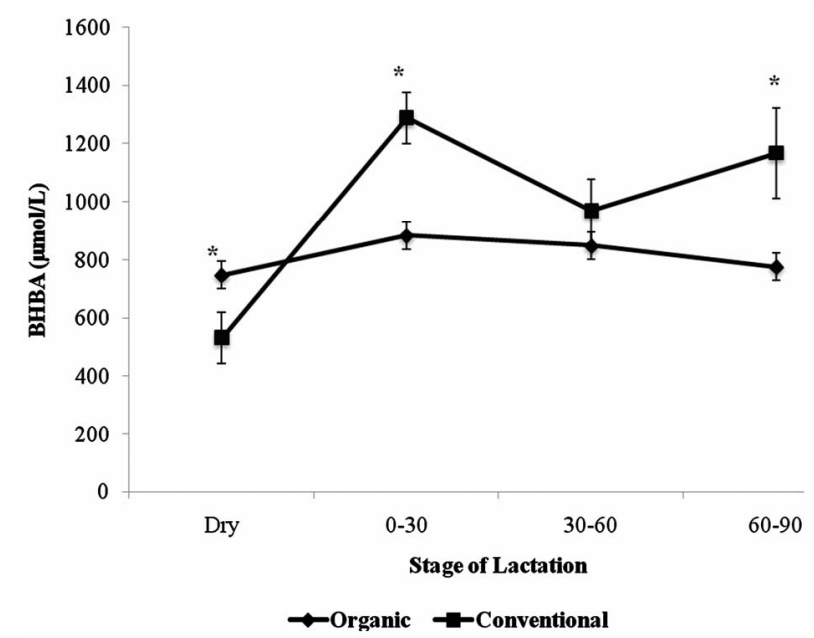

Figure 2. Least square means $\pm \mathrm{SE}$ serum concentrations of BHBA $(\mu \mathrm{mol} / \mathrm{L})$ in transition dairy cows. Blood samples were obtained from cows $(n=7)$ during the transition period and analyzed for metabolite content by ELISA. "LS means for farm type $\times$ stage of lactation differed $(\mathrm{P}<0.0001)$.

affected by farm type $(\mathrm{P}<0.0001)$, breed $(\mathrm{P}<$ $0.0001)$,stage of lactation $(\mathrm{P}<0.0001)$ and season $(\mathrm{P}<$ $0.0001)$. In addition, interactions of farm type by stage of lactation $(\mathrm{P}<0.0001)$ and tendency $(\mathrm{P}<0.07)$ for season by stage of lactation were also observed.

Cholesterol was higher $(\mathrm{P}<0.0001)$ in conventional dairy cows compared to cows managed under organic systems $(240.3 \pm 6.1$ vs. $128.9 \pm 2.3 \mathrm{mmol} / \mathrm{L}$, respectively). Concentrations of cholesterol were also higher $(\mathrm{P}$ $<0.0001)$ in Holsteins compared to Jerseys (195.8 \pm 3.2 vs. $173.3 \pm 4.8 \mathrm{mmol} / \mathrm{L}$, respectively). In addition, cholesterol was also higher $(\mathrm{P}<0.0001)$ in the cows during winter than in summer $(191.8 \pm 3.6$ vs. $177.3 \pm 4.0$ $\mathrm{mmol} / \mathrm{L}$, respectively).

Cholesterol concentrations were lower $(\mathrm{P}<0.0001)$ during the dry period, began an upward trend from 0 to $30 \mathrm{~d}$ and peaked between 60 to $90 \mathrm{~d}$ postpartum (Figure $3)$. The concentrations were also greater $(\mathrm{P}<0.0001)$ in most stages of lactation in conventional cows than organic cows except for the dry period (Figure 3 ). In addition, concentrations of cholesterol in cows tended $(\mathrm{P}<$ 0.07 ) to be more elevated in winter at day 0 to 30 and 30 to 60 postpartum than in summer (Figure 4).

\subsection{Lactate}

Farm type $(\mathrm{P}<0.0001)$, season $(\mathrm{P}<0.0001)$, breed $(\mathrm{P}$ $<0.03)$ affected serum concentrations of lactate of the cows. Neither stage of lactation $(\mathrm{P}<0.2)$ nor its two way interactions with other factors affected concentrations of lactate in the cows.

Greater $(\mathrm{P}<0.0001)$ concentrations of lactate were observed in cows under organic management than in those under conventional system $(4.00 \pm 0.13$ vs. $2.20 \pm$

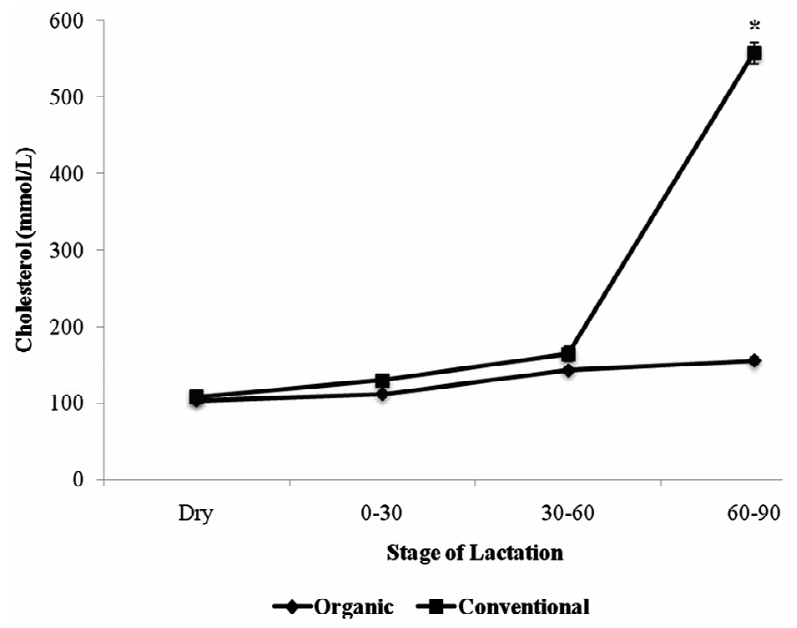

Figure 3. Least square means $\pm \mathrm{SE}$ serum concentrations of cholesterol $(\mathrm{mmol} / \mathrm{L})$ in transition dairy cows. Blood samples were obtained from cows $(n=7)$ during the transition period and analyzed for metabolite content by ELISA. ${ }^{*}$ LS means for farm type $\times$ stage of lactation differed $(\mathrm{P}<0.0001)$.

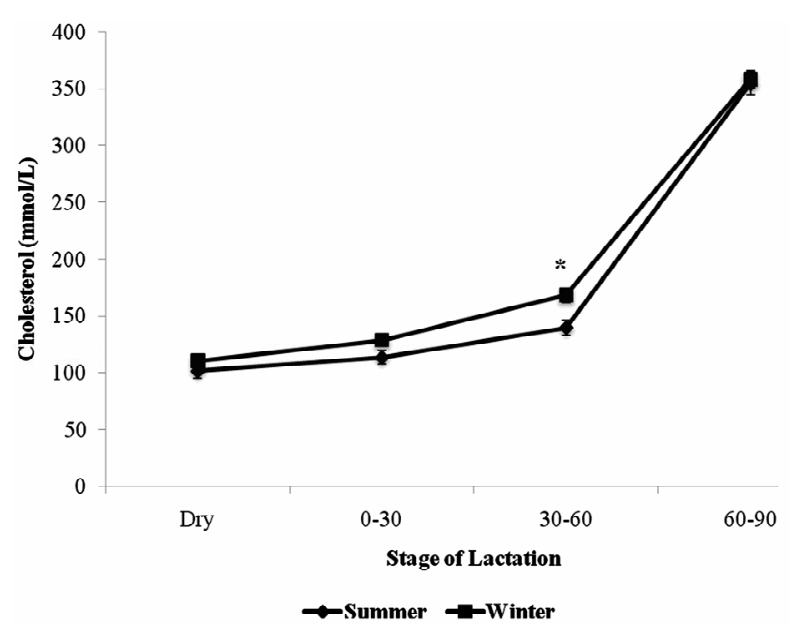

Figure 4. Least square means $\pm \mathrm{SE}$ serum concentrations of cholesterol $(\mathrm{mmol} / \mathrm{L})$ in transition dairy cows. Blood samples were obtained from cows $(n=7)$ during the transition period and analyzed for metabolite content by ELISA. ${ }^{*}$ LS means for season $\times$ stage of lactation tended to differ $(\mathrm{P}=0.07)$.

$0.33 \mu \mathrm{mol} / \mathrm{L}$, respectively, Figure 5). In addition, concentrations of lactate were also greater $(\mathrm{P}<0.0001)$ in cows during winter than in summer $(4.28 \pm 0.20$ vs. 1.92 $\pm 0.23 \mu \mathrm{mol} / \mathrm{L}$, respectively, Figure 5). Among breeds, concentrations of lactate were higher $(\mathrm{P}<0.03)$ in Holstein cows than in Jersey cows $(3.37 \pm 0.17$ vs. $2.83 \pm$ $0.26 \mu \mathrm{mol} / \mathrm{L}$, respectively, Figure 5).

\subsection{Glucose}

Season $(\mathrm{P}<0.001)$, breed $(\mathrm{P}<0.001)$, and stage of lactation $(\mathrm{P}<0.0001)$ affected concentrations of glucose in the cows. Two way interactions involving farm type or stage of lactation with the other factors did not $(\mathrm{P}<0.5)$ 


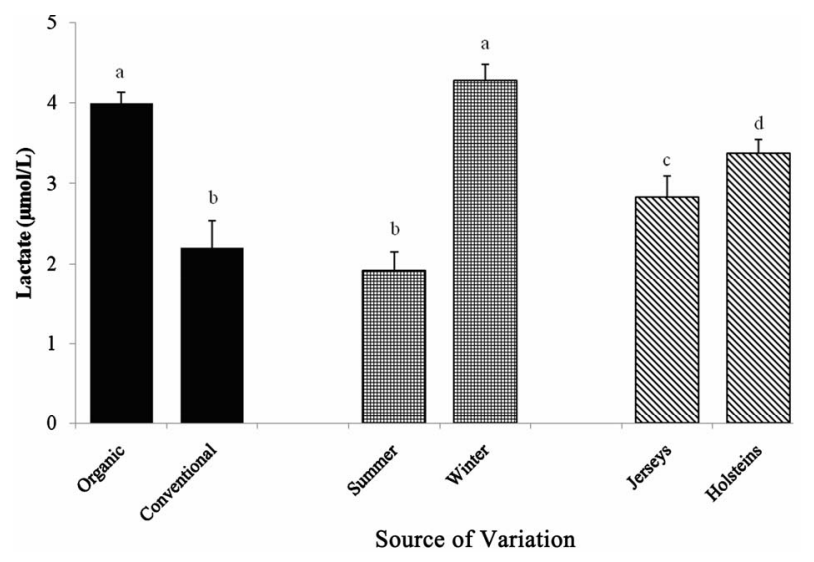

Figure 5. Least square means $\pm \mathrm{SE}$ serum concentrations of lactate $(\mu \mathrm{mol} / \mathrm{L})$ in transition dairy cows. Blood samples were obtained from cows $(n=7)$ during the transition period and analyzed for metabolite content by ELISA. a vs. b, LS means within source differed $(\mathrm{P}<0.0001)$; c vs. d, LS means within source differed $(\mathrm{P}<0.03)$.

affect concentrations of glucose in the cows.

Concentrations of glucose were greater in the cows during winter than in the summer season, and also in the Holsteins than in Jerseys (Figure 6). Concentrations were also greater during the dry period and intermediate between 30 to 60 and 60 to 90 days postpartum. However, least concentrations of glucose were observed during 0 to 30 days postpartum (Figure 6).

\subsection{Haptoglobin}

Haptoglobin concentrations in cows were affected by farm type $(\mathrm{P}<0.0001)$ and season $(\mathrm{P}<0.001)$. However, interactions of farm type by day tended $(\mathrm{P}=0.06)$ to affect haptoglobin levels in cows.

Conventional cows had higher concentrations of haptoglobin compared to cows in organic systems $(528.1 \pm$ 45.1 vs. $261.1 \pm 16.9 \mu \mathrm{g} / \mathrm{mL}$, respectively, Figure 7). In addition concentrations of haptoglobin were higher in cows during summer than winter (448.1 \pm 30.8 vs. 341.1 $\pm 27.2 \mu \mathrm{g} / \mathrm{mL}$, respectively, Figure 7). Concentrations of haptoglobin tended to greater in conventional than organic cows throughout the periods of study. A steady increase in haptoglobin was evident in conventional cows at initiation of lactation that remained much more elevated 30 to 60 and 60 to $90 \mathrm{~d}$ postpartum than in organic cows (Figure 8).

\section{DISCUSSION}

Data from this study showed that NEFA was higher in Holstein cows than Jersey cows and that it was also numerically higher during winter than in summer. We have also shown that during summer months cows in their initial stages of lactation ( 0 to $30 \mathrm{~d}$ ) were forced to mobilize more body fat than their counterparts during winter.

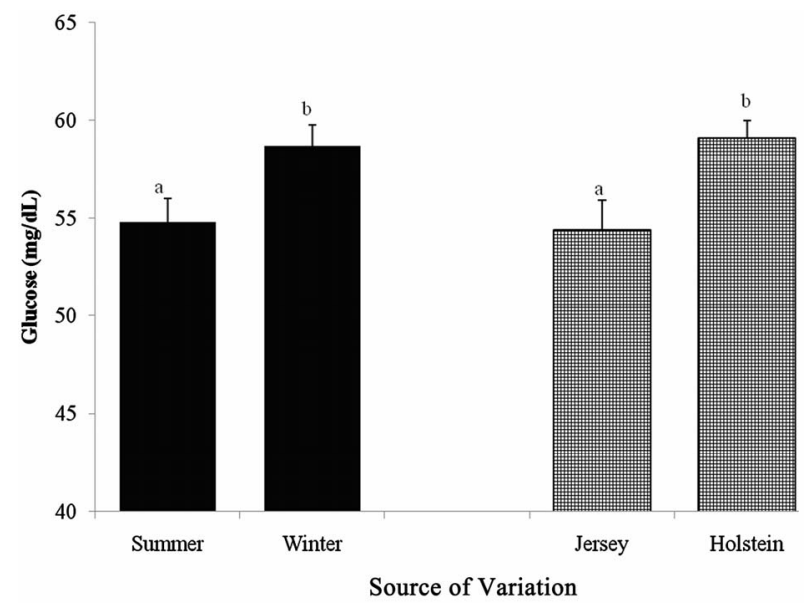

Figure 6. Least square means \pm SE serum concentrations of glucose $(\mathrm{mg} / \mathrm{dL})$ in transition dairy cows. Blood samples were obtained from cows $(\mathrm{n}=7)$ during the transition period and analyzed for metabolite content by ELISA. a vs. b, LS means within source differed $(\mathrm{P}<0.001)$.

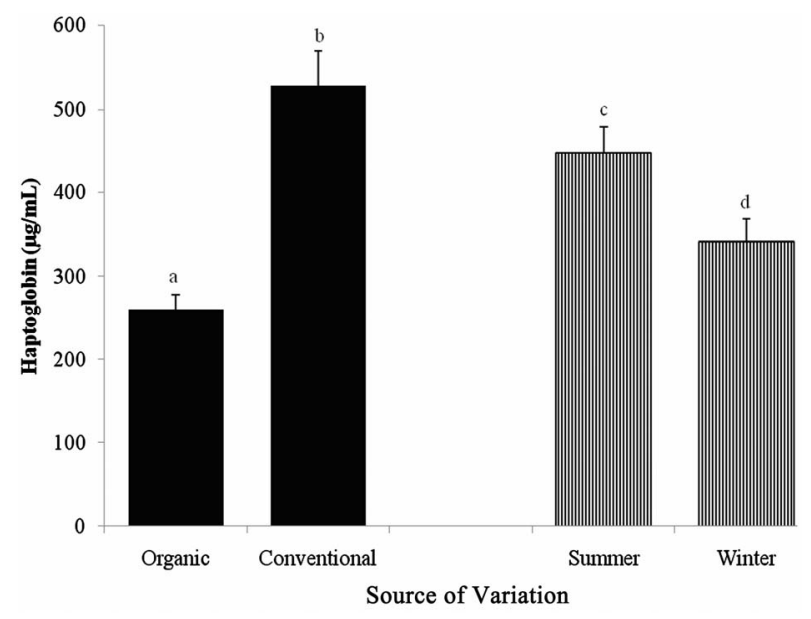

Figure 7. Least square means $\pm \mathrm{SE}$ serum concentrations of haptoglobin $(\mu \mathrm{g} / \mathrm{mL})$ in transition dairy cows. Blood samples were obtained from cows $(n=7)$ during the transition period and analyzed for metabolite content by ELISA. a vs. b, LS means within source differed $(\mathrm{P}<0.0001)$; c vs. d, LS means within source differed $(\mathrm{P}<0.001)$.

Interestingly, cows in peak lactation (60 to $90 \mathrm{~d}$ ) were the ones that mobilized more body fat during winter than their counterparts in the summer. It is possible to speculate that the observed phenomena were due preferably to differences in feeding systems that influenced cow physiology. During summer, most organic operations reduced grain levels in their rations to compensate for grazing opportunities available. As such transition dairy cows grazing summer pastures might have had lower DMI and/or more energy expenditure and thereby experienced some level of negative energy balance that necessitated mobilization of their body fat compared to their contemporaries during the winter. On the other hand the observed 


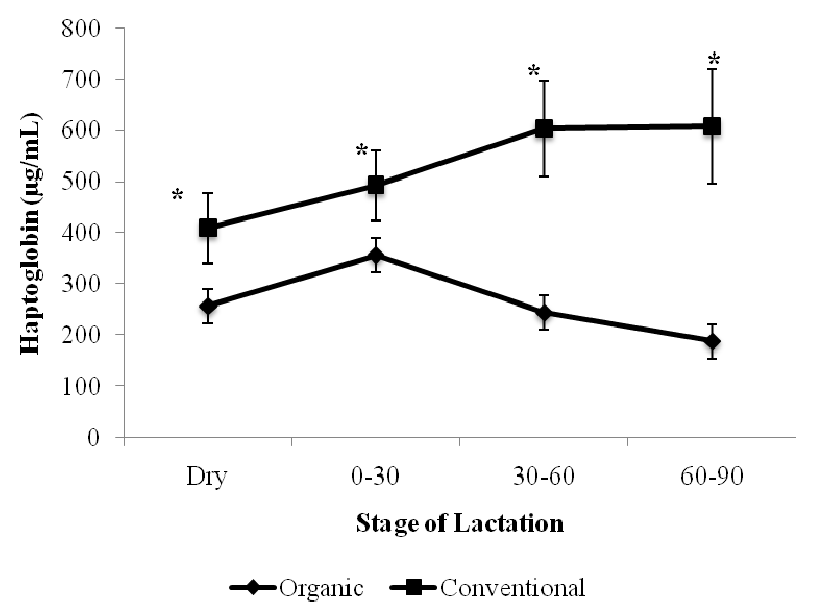

Figure 8. Least square means $\pm \mathrm{SE}$ serum concentrations of haptoglobin $(\mu \mathrm{g} / \mathrm{mL})$ in transition dairy cows. Blood samples were obtained from cows $(n=7)$ during the transition period and analyzed for metabolite content by ELISA. *LS means for farm type $\times$ stage of lactation tended to differ $(P=0.06)$.

phenomenon during 60 to $90 \mathrm{~d}$ in winter might have nothing to do with NEG, but might be related to the adverse effects of feeding high proportions of grain in the diet. Previous research from our lab $[8,9]$ has demonstrated an endotoxin induced increase in NEFA in transition cows fed high amounts of barley grain in the diet. Similarly, Steiger et al. [10] reported an initial endotoxin induced increase in plasma NEFA and glycerol in heifers following prolonged administration of bacterial lipopolysaccharides (LPS). Besides, a decrease in NEFA utilization by muscle tissue was linked to endotoxin induced increase in plasma NEFA [11].

Our results also revealed the differences in serum concentrations of BHBA among cows in conventional and those under organic systems. Furthermore, farm type by stage of lactation effect was also observed. Thus concentrations of BHBA were greater in the conventional than organic cows at 0 to 30 and 60 to $90 \mathrm{~d}$ postpartum, but remained lower during the dry period. Similar observations were reported in a Swedish study that also profiled metabolites in organic and conventional cows [7]. In that study, concentrations of BHBA in conventional cows surpassed the benchmark threshold of 1.0 $\mathrm{mmol} / \mathrm{L}$ [12] between 10 to 29 DIM indicating presence of subclinical ketosis in those cows. In the present study, concentrations of BHBA in conventional cows during the same period were $1.29 \mathrm{mmol} / \mathrm{L}$, which was also higher than the threshold value. However, seasonal variations in BHBA were also observed in our study. Thus, during summer season, serum concentrations of BHBA tended to be lower than those observed in the cows during winter. This might indicate fewer incidences of metabolic disturbances during summer than winter. Mechanisms behind this observation remain obscure. However, we are tempted to speculate that because most organic systems incorporated summer grazing in their nutritional programs; it might have resulted in lower usage of grains in their diets during summer months, hence reduced incidences of metabolic disturbances. Contrary to these observations, previous work on metabolic health status of organic dairy herds in the United Kingdom reported tendencies for more subclinical ketosis in organic cows [13]. By observing higher concentrations of BHBA in milk from organic vs. conventional cows, the authors concluded that BHBA content in milk increased when cows were not fed to meet their energy requirements. However, the authors also concluded that in the end, organic cows adjust their milk production to adapt to a lower level of feeding. Similarly, Andersen et al. [14] found greater concentrations of BHBA in dairy cows fed diets low energy density diets in early lactation.

Another observation obtained from this study was that concentrations of cholesterol in plasma of cows varied between conventional and organic cows. In fact, cholesterol was higher in conventional dairy cows throughout most of the study periods compared to cows managed under organic systems. In addition, greater concentrations of cholesterol in cows were also observed during winter at 0 to 30 and 30 to 60 postpartum than in summer. Cholesterol is a component of lipoproteins and its concentrations in serum is an indication of overall lipoprotein concentrations. The significance of cholesterol concentration in serum is somewhat controversial. Reduced lipoprotein concentrations are characteristic of the prepartum period [15] and are associated with liver metabolism and increased incidences of diseases [16]. Ametaj et al. [9] reported reduced levels of cholesterol in dairy cows fed diets steeped with $45 \%$ grain and postulated that cholesterol was being used to sequester endotoxaemia resulting from the high grain feeding. Hypercholesteremia may be associated with an improvement in energy balance [17]. In that study, severe losses in BCS were observed in dairy cows around parturition when cholesterol concentrations in circulation were low. Thus, greater cholesterol levels observed in conventional cows and again in early lactating cows during winter might indicate some degree of improvement in their energy balance.

Our results also indicated greater concentrations of lactate in organic vs. conventional cows, and in winter than summer, as well as in Holsteins than in Jersey cows. This higher lactate in organic dairy cows was unexpected. Previous reports that have associated increased plasma lactate in dairy cows to prevailing conditions of endotoxemia $[9,18,19]$. Therefore, it could be speculated that during feeding regimen during winter might have contributed to the observed differences in lactate concentrations in these cows. Similarly, Holstein cows are to 
known consume more feed per unit body weight compared to Jersey cows and in turn produce more milk than Jersey cows too. These inherent traits make Holteins more prone to metabolic disturbances than Jerseys, hence the difference in the plasma lactate levels. Just like in lactate, higher concentrations of glucose in cows were also observed during winter and in Holsteins. Increased concentrations of glucose in cows during winter allude to the fact that more gluconeogenic diets were probably used during that time. Ametaj et al. [9] reported increased plasma glucose in cows when fed $\geq 30 \%$ grains in the diet. Similarly, Van Knegsel et al. [4] observed higher concentrations of glucose and decreased risk of metabolic disorders in transition dairy cows fed diets rich in fermentable carbohydrates.

A drastic increase in haptoglobin was evident in conventional cows at initiation of lactation that remained much more elevated 30 to 60 and 60 to $90 \mathrm{~d}$ postpartum than in organic cows. A similar pattern of haptoglobin secretion has been reported in dairy cows and is believed to be in response to the traumatic experience during calving and acute phase response preceding calving [20-22]. It is also possible to speculate that variability of diets fed between the systems might contribute to this observed pattern on haptoglobin secretion in the cows. Indeed grains make up $30 \%$ to $45 \%$ of most conventional dairy rations in Alberta and Canada as whole. Feeding cows higher amounts of grains in the diet has been associated with increased concentrations of endotoxin in the rumen $[8,23]$. Translocation of endotoxin into the portal and peripheral circulation stimulates cytokine production by macrophages. These in turn stimulate secretion of haptoglobin and other acute phase proteins by hepatocytes. Indeed, haptoglobin has been used as an indicator of poor health in cattle by numerous studies $[20,24,25]$. Therefore, it is imperative that we observed differences in amounts of haptoglobin between cows in our study.

\section{CONCLUSION}

Taken together, these data indicate that metabolic changes associated with initiation of lactation are preceded by an acute phase response in dairy cows, and that cows in organic systems seem to be healthier than cows under conventional systems. These differences might be due to differences in nutritional management in the two systems. However, more studies might be required to fully understand this phenomenon.

\section{REFERENCES}

[1] Hardeng, F. and Edge, V.L. (2001) Mastitis, ketosis, and milk fever in 31 organic and 93 conventional Norwegian dairy herds. Journal of Dairy Science, 84, 2673-2679. doi:10.3168/jds.S0022-0302(01)74721-2
[2] Ingvartsen, K.L., Dewhurst, R.J. and Friggens, N.C. (2003) On the relationship between lactational performance and health: Is it yield or metabolic imbalance that cause production diseases in dairy cattle? A position paper. Livestock Production Science, 83, 277-308. doi:10.1016/S0301-6226(03)00110-6

[3] Kokkonen, T., Taponen, J., Anttila, T., Syrjälä-Qvist, L., Delavaud, C., Chilliard, Y., Tuori, M. and Tesfa, A.T. (2005) Effect of body fatness and glucogenic supplement on lipid and protein mobilization and plasma leptin in dairy cows. Journal of Dairy Science, 88, 1127-1141. doi:10.3168/jds.S0022-0302(05)72779-X

[4] Van Knegsel, A.T.M., van den Brand, H., Dijkstra, J. and Kemp, B. (2007) Effects of dietary energy source on energy balance, metabolites and reproduction variables in dairy cows in early lactation. Theriogenology, 68, S274S280. doi:10.1016/j.theriogenology.2007.04.043

[5] Roesch, M., Doherr, M.G. and Blum, J.W. (2005) Performance of dairy cows on Swiss farms with organic and integrated production. Journal of Dairy Science, 88, 2462-2475. doi:10.3168/jds.S0022-0302(05)72924-6

[6] Hamilton, C., Hansson, I., Ekman, T., Emanuelson, U. and Forslund, K. (2002) Health of cows, calves and young stock on 26 organic dairy herds in Sweden. Veterinary Record, 150, 503-508. doi:10.1136/vr.150.16.503

[7] Fall, N., Gröhn, Y.T., Forslund, K., Essen-Gustafsson, B., Niskanen, R. and Emanuelson, U. (2008) An observational study on early-lactation metabolic profiles in Swedish organically and conventionally managed dairy cows. Journal of Dairy Science, 91, 3983-3992. doi:10.3168/jds.2008-1099

[8] Emmanuel, D.G., Dunn, S.M. and Ametaj, B.N. (2008) Feeding high proportions of barley grain stimulate an inflammatory response in dairy cows. Journal of Dairy Science, 91, 606-614. doi:10.3168/jds.2007-0256

[9] Ametaj, B.N., Emmanuel, D.G., Zebeli, Q. and Dunn, S.M. (2009) Feeding high proportions of barley grain in a total mixed ration perturbs diurnal patterns of plasma metabolites in lactating dairy cows. Journal of Dairy Science, 92, 1084-1091. doi:10.3168/jds.2008-1465

[10] Steiger, M., Senn, M., Altreuther, G., Werling, D., Sutter, F., Kreuzer, M. and Langhans, W. (1999) Effect of a prolonged low-dose lipopolysaccharide infusion on feed intake and metabolism in heifers. Journal of Animal Science, 77, 2523-2532.

[11] Romanowsky, A.J., Bagby, G.J., Bockman, E.L. and Spitzer, J.J. (1980) Free fatty acid utilization by skeletal muscle after endotoxin administration. American Journal of Physiology, 239, E391-E395.

[12] Whitaker, D.A., Kelly, J.M. and Smith, E.J. (1983) Subclinical ketosis and serum beta-hydroxybutyrate levels in dairy cattle. British Veterinary Journal, 139, 462-463.

[13] Rutherford, K.M.D., Langford, F.M., Jack, M.C., Sherwood, L., Lawrence, A.B. and Haskell, M.J. (2009) Organic dairy cow management and indicators of energy balance. Veterinary Record, 165, 147-148. doi:10.1136/vr.165.5.147

[14] Andersen, J.B., Friggens, N.C., Larsen, T., Vestergaard, M. and Ingvartsen, K.L. (2004) Effect of energy density in the diet and milking frequency on plasma metabolites 
and hormones in early lactation dairy cows. Journal of Veterinary Medicine Series A, 51, 52-57. doi:10.1111/j.1439-0442.2004.00605.x

[15] Arave, C., Miller, R. and Lamb, R. (1975) Genetic and environmental effects on serum cholesterol of dairy cattle of various ages. Journal of Dairy Science, 58, 423-427. doi:10.3168/jds.S0022-0302(75)84582-6

[16] Kaneene, J.B., Miller, R., Herdt, T.H. and Gardiner, J.C. (1997) The association of serum nonesterified fatty acids and cholesterol, management and feeding practices with peripartum disease in dairy cows. Preventive Veterinary Medicine, 31, 59-72. doi:10.1016/S0167-5877(96)01141-5

[17] Cavestany, D., Blanc, J.E., Kulcsar, M., Uriarte, G., Chilibroste, P., Meikle, A., Febel, H., Ferraris, A. and Krall, E. (2005) Studies of the transition cow under a pasturebased milkproduction system: Metabolic profiles. Journal of Veterinary Medicine Series A, 52, 1-7. doi:10.1111/j.1439-0442.2004.00679.x

[18] Zebeli, Q., Dunn, S.M. and Ametaj, B.N. (2011) Perturbations of plasma metabolites correlated with the rise of rumen endotoxin in dairy cows fed diets rich in easily degradable carbohydrates. Journal of Dairy Science, 94, 2374-2382. doi:10.3168/jds.2010-3860

[19] Elsasser, T.H., Caperna, T.J., Li, C.-J., Kahl, S. and Sartin, J.L. (2008) Critical control points in the impact of the proinflammatory immune response on growth and metabolism. Journal of Animal Science, 86, E105-E125. doi:10.2527/jas.2007-0634

[20] Kovác, G., Tóthová, C., Nagy, O., Seidel, H. and Kon- vicná, J. (2009) Acute phase proteins and their relation to energy metabolites in dairy cows during the pre- and postpartal period. Acta Veterinaria Brno, 78, 441-447. doi:10.2754/avb200978030441

[21] Cairoli, F., Battocchio, M., Veronesi, M.C., Brambilla, D., Conserva, F., Eberini, I., Wait, R. and Gianazza, E. (2006) Serum protein pattern during cow pregnancy: Acute-phase proteins increase in the peripartum period. Electrophoresis, 27, 1617-1625. doi:10.1002/elps.200500742

[22] Uchida, E., Katoh, N. and Takahashi, K. (1993) Appearance of haptoglobin in serum from cows at parturition. Journal Veterinary Medicine Science, 55, 893-894. doi:10.1292/jvms.55.893

[23] Ametaj, B.N., Bradford, B.J., Bobe, G., Nafikov, R.A., Lu, J., Young, W. and Beitz, D.C. (2005) Strong relationships between mediators of the acute phase response and fatty liver in dairy cows. Canadian Journal of Animal Science, 85, 165-175. doi:10.4141/A04-043

[24] Guzelbektes, H., Sen, I., Ok, M., Constable, P.D., Boydak, M. and Coskun, A. (2010) Serum amyloid A and haptoglobin concentrations and liver fat percentage in lactating dairy cows with abomasal displacement. Journal of Veterinary Internal Medicine, 24, 213-219. doi:10.1111/j.1939-1676.2009.0444.x

[25] Yoshino, K., Katoh, N., Takahashi, K. and Yuasa, A. (1993) Possible involvement of protein kinase C with induction of haptoglobin in cows by treatment with dexamethasone and by starvation. American Journal of Veterianry Research, 54, 689-694. 